\title{
Effectiveness of flipped language learning classrooms and students' perspectives
}

\author{
Munassir Alhamami \\ Munassir7@gmail.com \\ English Department, Faculty of Languages and Translation, King Khalid University, \\ Abha, Saudi Arabia \\ Building A, Gate 3 King Khalid University PO Box 9100 Abha 61413, \\ Saudi Arabia \\ Mohsin Raza Khan \\ mohsinkku@gmail.com \\ English Department, Faculty of Languages and Translation, King Khalid University, \\ Abha, Saudi Arabia \\ Building A, Gate 3 King Khalid University PO Box 9100 Abha 61413, \\ Saudi Arabia
}

Received: December 25, 2018; $\quad$ Accepted: February 17, 2019; $\quad$ Published: March 9, 2019

\begin{abstract}
The objectives of this study are to investigate the usefulness of the flipped language learning approach in a reading course, and to understand students' attitudes and self-efficacy toward it. A quasi-experimental pretest-post-test design was employed. Two treatments were designed, namely, face-to-face and online, using the flipped classroom approach. A total of 43 students participated in the pre-tests and post-tests, administered in both treatments. The data were collected from the results of pre-tests and post-tests. A regression test and t-tests were performed to analyze the data. A significant difference was observed between the students' results in the pre-tests and post-tests in both treatments. However, the post-test results in both treatments show no significant difference. This finding indicates that both face-to-face and flipped classroom approaches can be equally effective in enhancing the reading skill of Level 1 students. The survey results also indicate that students have more positive attitudes toward the flipped learning approach than society in general does toward it. Accordingly, teachers are advised to select a language-teaching Journal on English as a Foreign Language, 9(1), 71-86

Copyright $@ 2019$ by JEFL, p-ISSN 2088-1657; e-ISSN 2502-6615
\end{abstract}


approach that is helpful for students. They should also consider the perspectives of students. Improvement in reading skill is not necessarily attributed to only one of the approaches analyzed in this study.

Keywords: flipped classroom; students' attitudes; students' achievement; flipped language learning; language learning online

How to cite this paper: Alhamami, M., \& Khan, M. R. (2019). Effectiveness of flipped language learning classrooms and students' perspectives. Journal on $\begin{array}{lllll}\text { English as a Foreign Language, 9(1), 71-86. } & \end{array}$

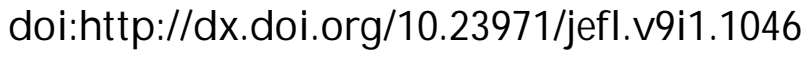

DOI: http://dx.doi.org/10.23971 ßjefl.v9i1.1046

Language learning or teaching approaches have often been the concern of language teachers and practitioners who have been searching for methods that are most suitable for their classroom needs. Since the advent of modern technology and the implementation of e-learning, research and academic discussions have often focused on which language learning or teaching approach, whether online or face-to-face, can be effective in the classroom. Although the face-to-face approach in language learning classrooms has provided excellent results, language teachers and practitioners have been showing interest in using advanced technologies in their classes. In certain contexts, language instructors prefer to conduct full online language learning classes without any face-to-face interaction (Alhamami, 2018a; Satar \& Akcan, 2018). Moreover, these online classes have been proven effective in certain situations, especially where attending face-to-face language learning classes is difficult for students.

The major problem raised in the context of face-to-face language learning is that the teachers have insufficient time to conduct activities and practice their language skills in the classroom. Language instructors spend more time explaining the lesson and illustrating the contents of the lesson than implementing activities and practicing the language in face-to-face settings. Similarly, in the online context, observing the students while they are performing activities and supporting them while completing the learning tasks might be difficult for the teachers (Alhamami \& Costello, 2019). Notably, observing the students while they are performing the activities can help the instructors evaluate the learners' performances. 
In such situations, the flipped classroom approach can be an effective solution that can help teachers observe the students while they are practicing and giving the output rather than receiving the input. The flipped classroom is adapted by school instructors for making students active learners (Basal, 2015; Correa, 2015; Lee, \& Wallace, 2018). The flipped classroom is a remedy for passive learning because it enables the students to participate and share their knowledge with their teachers and classmates in face-to-face situations.

Language practitioners have recently increased the use of flipped language learning classrooms (Alhamami, 2018a). However, limited research on their effectiveness has been published. Several factors might affect the students' performance in flipped language learning classrooms, such as both student and societal attitudes and students' self-efficacy to learn a language through this approach. Investigating these areas can help language researchers and practitioners understand the behavior of their students toward the flipped classroom approach. This study investigates the effectiveness of flipped language learning classrooms and language students' beliefs regarding flipped language learning classes in an EFL course.

The flipped classroom is associated with active learning. Andrews, Leonard, Colgrove, and Kalinowski (2011) defined active learning as students start doing the given task for understanding the concept after the instructor's lecture. The results of published research show that active learning has positive outcomes. Berrett (2012) stressed that the flipped classroom has been expanding to improve the teaching approach that requires students' preparation outside the classroom in order to make them active in the class.

In foreign language learning classes, a flipped language learning class can be defined as a teaching method that utilizes asynchronous language learning materials, such as videos, audios, PowerPoint presentations, hypertexts, and images to study the language outside the classroom, practice the language, and perform various activities and tasks in face-to-face classrooms. Several language researchers, such as Hung (2017) and Wu, Hsieh, and Yang (2017), call for further research on using the flipped classroom approach in language learning classes. Other published studies have focused on flipped language learning classrooms. However, an increasing need arises to explore the effectiveness of this approach in various contexts and in relation to specific language learning skills. In the Taiwanese context, flipped language learning facilitated the students' attainment of improved learning outcomes, development of better attitudes toward their learning experiences, and a 
commitment to exert further efforts in the learning process (Hung, 2015). In the Indonesian context, students showed a positive attitude towards the implementation of flipped learning for writing skills (Fauzan \& Ngabut, 2018).

This research article uses 'Ajzen's theory of planned behavior to investigate students' attitudes, self-efficacy, and intention to learn a foreign language using the flipped language learning approach. In 1985, Ajzen introduced the theory of planned behavior as an addition to the theory of reasoned action (Fishbein \& Ajzen, 2011). Ajzen's extended theory of reasoned action by adding perceived behavioral control as the third predicting cognitive variable to intention. In the context of this study, a student's intention to learn is the central factor in theory of planned behavior. Intention refers to the motivational variables that influence a person's behavior. The intention indicates the magnitude of the exerted efforts planned when performing the behavior. If the intention for engaging in behavior is stronger, it will increase the performance (Ajzen, 2015). Ajzen (2007) stressed that the commonly mentioned behavioral, normative, and control views are expected to be the noticeable beliefs among a particular group of people. In the context of the study, these beliefs regulate dominant students' attitudes, students' subjective norms, and students' perceptions of behavioral control. Ajzen (2007) maintained that important beliefs focus on the particular behavior of interest and serve as the fundamental explanatory constructs in his theory.

Ajzen's theory is designed to explain and predict human behaviors using intention. Intention is predicted from three constructs. The first is a person's attitude toward behavior. It denotes the point to which the enactment of the student's behavior is positively or negatively valued. It is intent upon the overall set of accessible behavioral beliefs linking the behavior to various outcomes and attributes. In this study, attitude towards behavior refers to the language students' attitude toward learning a foreign language using the flipped language learning approach. The second construct is subjective norms. It refers to perceived social pressure to participate or not to participate in a behavior. Subjective norms are intent upon the total set of accessible normative perspectives on the expectations of significant others. In this study, subjective norms refer to the beliefs of significant others that language students can learn a foreign language by using the flipped language learning approach (Ajzen, 2015).

The third construct is perceived behavioral control. It means people's beliefs of their ability to accomplish a given behavior. Perceived behavioral 
control is formed by the total set of accessible control views, that is, the presence of variables that may ease or hinder the performance of the behavior. Perceived behavioral control is an accurate reflection of actual behavioral control. Thus, together with intention, it can be utilized to predict behaviors. In this study, perceived behavioral control refers to language students' beliefs regarding their ability to learn a foreign language using the flipped language learning approach. According to Ajzen (2006), these three factors can predict a person's intention, which indicates his/her readiness to execute a given behavior. Thus, intention is considered to be the direct antecedent of behavior. Thus, Azjen's theory of planned behavior can be represented as follows: Intention $=\sum$ attitude towards behavior + subjective norms + perceived behavioral control.

Although most of the published papers on flipped language classrooms have focused on students' attitudes toward them, the researchers have not used a valid and reliable theoretical framework to study their students' attitudes. This paper contributes to the literature by investigating the language students' attitudes using a theoretical framework. To the best of our knowledge, we have not come across published papers that use Ajzen's theory of planned behavior as a theoretical framework to elicit, understand, and predict language students' beliefs on flipped language learning classrooms in a reading course. Predicting language students' intention to learn in flipped language learning classrooms can help researchers provide earlier interventions to increase students' positive attitudes toward flipped language learning classrooms.

In addition, most of the published papers on flipped language learning classrooms focus on attitudes and motivation. Few published papers study language students' achievements using flipped language learning classrooms. The present paper contributes to the literature by investigating the language students' achievements in flipped language learning classrooms. The paper measures students' achievements using the paired samples t-test. Therefore, the research questions are: 1) to what extent can Ajzens' theory of planned behavior assist language researchers in understanding and predicting language students' beliefs on flipped language learning classrooms?; and 2) how does students' performance in a reading course differ using two teaching approaches, namely, face-to-face classrooms and flipped classrooms? 


\section{METHOD}

\section{The Context of the Study}

A quasi-experimental pre-test/post-test design was used. The researchers measured a dependent variable (test scores) in the same group of participants before the treatment and after the treatment (Thyer, 2012). The study was conducted at a Saudi university. The university offers two intensive courses as core courses for students who join the colleges of computer, engineering, medicine, and sciences because these colleges use English as a medium of instruction. The first course is offered in the first semester and the second course in the second semester. Each course has a separate textbook for each language learning skills namely: listening, speaking, reading, and writing. This study was conducted during the first-semester course known as ENG-011. This study was conducted on reading skills. The study uses a textbook called Well Read 1. This textbook helps students improve their reading skills in EFL. This textbook has eight units, each focusing on a specific topic and reading strategies.

\section{Participants}

The participants are freshmen students in their first semester at university. They are Saudi, and they speak Arabic as their first language. They are between 19 and 21 years old. They have the same secondary and intermediate education because the curriculum is unified among all Saudi secondary and intermediate schools. The students graduated from scientific streams. Saudi secondary education consists of two main streams, namely, scientific and literary. Those who graduate from a scientific stream at the secondary level can join the colleges of medicine, engineering, computer, and sciences. These students are not required to take any English language proficiency tests to enroll in the university. Due to these factors, he researchers assume and have observed that no large difference exists among the students' proficiency level in English.

\section{Design of Study and Instruments}

First, the researchers gave the participants a pre-test in a face-to-face setting. The pre-test was on the reading content that they would study in Chapter 1 . Then, one of the researchers taught the students Chapter 1 from the reading textbook in a face-to-face setting. The teaching process lasted for an hour. The instructor had to cover and teach other skills, such as writing and 
listening. After the students completed the reading part, the instructor administered a post-test with 20 items.

Second, the researchers designed the questionnaire. The researchers adapted valid and reliable published surveys, such as those by Ajzen (2006), Fishbein and Ajzen (2011), and Alhamami (2018b), as guidelines to design the current study survey. The questionnaire consisted of four sections. There were twenty items total, five items per section. The first section measured the participants' attitudes toward flipped language learning classrooms. The second measured the participants' subjective norms to learn using flipped language learning classrooms. The third measured the participants' perceived behavioral control regarding flipped language learning classrooms. The fourth section measured the participants' intention to study in flipped language learning classrooms. The items were presented in a nonsystematic order to ensure reliability. The items utilized to assess attitudes were interspersed with those utilized to measure subjective norms and perceived behavioral control. The survey item numbers 1,5, 9, 13, and 17 assessed intention; 2, 6, 10, 14, and 18 assessed attitude towards behavior; 3, 7, 11, 15, and 19 assessed subjective norms; and 4, 8, 12, 16, and 20 assessed perceived behavioral control. Appendix 1 contains more details about the questionnaire items.

Third, the researchers distributed the questionnaire among the participants prior to starting the flipped language learning classroom. Then, the students took an online pre-test concerning the second chapter of the same reading textbook. After that, they had online reading lessons regarding the second chapter that lasted for approximately 50 minutes. The next day, when the students met face-to-face in the classroom, they were given other practice activities for the second chapter of reading text. Finally, the students took the post-test as homework on what they had studied in the second chapter. The post-test items were similar to the pre-test items. Each test consisted of 20 marks.

\section{FINDINGS}

\section{Pre-test and Post-test Face-to-face Treatment}

Using SPSS, the researchers conducted a paired sample t-test for evaluating a statistically significant difference between the mean of face-to-face treatment scores before and after teaching in a face-to-face setting. The results of the paired sample $\mathrm{t}$-test were significant; $\mathrm{t}(42)=5.49, \mathrm{p}<0.00$, indicating a significant increase from the pre-test scores $(M=13.21, S D=3.95, N=43)$ to the

Journal on English as a Foreign Language, 9(1), 71-86

Copyright @ 2019 by JEFL, p-ISSN 2088-1657; e-ISSN 2502-6615 
post-test scores $(\mathrm{M}=16.67, \mathrm{SD}=1.96, \mathrm{~N}=43)$. The mean increase was 3.46, with 95\% confidence interval for the difference between the means of 2.19 to 4.73 . The researchers rejected the null hypothesis.

\section{Pre-test and Post-test Flipped Treatment}

Using SPSS, the researchers conducted a paired sample t-test to measure whether a statistically significant difference existed between the mean of flipped treatment scores before and after teaching using the flipped language learning classroom approach. The results of the paired sample t-test were significant, $\mathrm{t}(42)=4.03, \mathrm{p}<0.00$, indicating a significant increase from the pretest scores $(\mathrm{M}=14.52, \mathrm{SD}=3.56, \mathrm{~N}=43)$ to the post-test scores $(\mathrm{M}=16.83, \mathrm{SD}=$ $2.65, \mathrm{~N}=43$ ). The mean increase was 2.31 , with $95 \%$ confidence interval for the difference between the means of 1.15 to 3.47 . The researchers rejected the null hypothesis.

\section{Comparison of Post-tests in Both Treatments}

Using SPSS, the researchers conducted a paired sample t-test to assess whether a statistically significant difference existed between the mean of faceto-face treatment post-test scores and flipped language learning classroom approach post-test scores. The results of the paired sample t-test were insignificant, $\mathrm{t}(42)=0.36, \mathrm{p}=0.72$, indicating no significant increase from the post-test of the face-to-face treatment scores $(\mathrm{M}=16.67, \mathrm{SD}=1.96, \mathrm{~N}=43)$ to the flipped language learning classroom post-test scores $(\mathrm{M}=16.83, \mathrm{SD}=2.65, \mathrm{~N}=$ 43). The mean increase was only 0.17 .

\section{Survey Results on Flipped Language Learning Classrooms}

The researchers transferred the survey data from Excel spreadsheets to SPSS, statistical software that checks scale reliability. Cronbach's alpha was used to measure the internal consistency of the items in each section. Cronbach's alpha results affirmed the acceptable reliability of the scale across the four sections, as shown in Table 1. Twenty-four participants answered the questionnaire. 
Table 1. Internal Consistency Results Using Cronbach's Alpha $(\mathrm{n}=24)$

\begin{tabular}{lll|}
\hline Variables & $K$ & Alpha \\
\hline Intention & 5 & 0.99 \\
\hline Direct attitude towards behavior & 5 & 0.96 \\
\hline Direct subjective norms & 5 & 0.97 \\
\hline Direct perceived behavioral control & 5 & 0.97 \\
\hline
\end{tabular}

Note: $k=$ number of items in the construct

\section{Regression Test Results}

The means of the three aspects of planned behavior constructs (attitude towards behavior, subjective norms, and perceived behavioral control) were used to predict the mean of intention $(n=24)$. Considered together, the three variables significantly predicted intention ( $p<0.00$ ), with a 97\% overlap between the three predictors and the outcome of intention. When predicting intention, the results erred by approximately 0.26 intention-rating points on the basis of a scale from 1 to 6 . Table 2 displays the mean and standard deviation results. A lower mean indicates positive agreement and likeness; a higher mean indicates disagreement and variance.

Table 2. Descriptive Statistics $(n=24)$

\begin{tabular}{|c|c|c|c|c|}
\hline & Minimum & Maximum & Mean & $\begin{array}{l}\text { Std. } \\
\text { Deviation }\end{array}$ \\
\hline Intention mean & 1.00 & 6.00 & 1.8917 & 1.55701 \\
\hline $\begin{array}{l}\text { Attitude towards behavior } \\
\text { mean }\end{array}$ & 1.00 & 6.00 & 1.8667 & 1.53415 \\
\hline Subjective norms mean & 1.00 & 6.00 & 2.0750 & 1.68349 \\
\hline $\begin{array}{l}\text { Perceived behavioral } \\
\text { control mean }\end{array}$ & 1.00 & 6.00 & 2.0417 & 1.56370 \\
\hline
\end{tabular}

\section{DISCUSSION}

In the face-to-face treatment setting, the students performed well on the post-test, and there was a significant increase in their post-test scores. This finding indicates that the face-to-face language learning teaching methods were effective and lead to significant improvements in the students' level. Language instructors should help students to effectively use the resources they possess in face-to-face settings. Assisting language learners with extra learning materials can help the instructors achieve the learning outcomes for the course. Furthermore, language learners' grades can improve by the end of the semester. 
Similarly, the results of the pre-test and post-test administered in the flipped treatment also showed a significant increase in scores on the post-test. However, the post-test findings for both treatments (face-to-face and flipped classroom) illustrate a relatively slightly larger (0.17) increase in the flipped classroom post-test. The results of both approaches indicate that students performed well in the reading course, and both treatments contributed equally toward enhancing the reading skills of Level 1 students. This finding shows that both treatments are effective and can lead to significant results. Moreover, learning a foreign language using the flipped approach can lead to the same learning outcomes as in face-to-face settings.

The results of this study support the findings of previous researchers (e.g., Hung, 2017; Wu et al., 2017). The flipped language learning approach is an effective strategy that can lead to significant improvements in students' grades in language reading tests. However, this approach is not superior to the face-toface language learning approach. According to the results of this study, both treatments lead to the same results. Other important factors, such as teachers, textbooks, students' future needs, and learners' attitudes toward the class content, teachers, and teaching methods, might influence learners' achievement in reading skill examination results. Thus, one cannot say that modern technology achieves learning outcomes more or less than traditional approaches. This result is in accordance with the findings of Grgurović, Chapelle, and Shelley (2013) and Zhao (2003). In both studies, the researchers found that pedagogies for foreign language teaching supported by computer technology were only as effective as those without computer technology. Technology-supported language learning was only as effective as traditional teacher-led instruction. Findings from previous studies and the current study stress that teacher's play a more important role in improving learners' language proficiency than modern technology does. Therefore, teachers' training and proficiency development programs are necessary for language teachers to improve their skills and update their knowledge. Providing language teachers with provisional development courses can improve their proficiency, and this in turn, can be reflected in their students' proficiency.

In view of Ajzen's theory of planned behavior, which represents the students' attitudes, self-efficacy, and intention, and combines three constructs, namely, attitude towards behavior, subjective norms, and perceived behavioral control, the results of the Cronbach's alpha validated survey items for using the flipped classroom approach in the foreign language classroom. Table 2 shows high intention toward the use of the flipped classroom approach. Although the 
subjective norms and perceived behavioral control were satisfactory, the students' attitudes toward the flipped classroom were positive because the society around, them, such as parents and family members, were unfamiliar with the flipped language learning approach. Higher positive attitudes and lower self-efficacy might be due to the unfamiliarity of the learners with the flipped language learning approach. The more the learners experienced the flipped language learning approach, the more positive their attitudes towards behavior, subjective norms, and perceived behavioral control. Therefore, using the flipped classroom approach to enhance the reading skills of EFL students can be helpful.

\section{CONCLUSION}

Considering the nearly similar results of the post-tests in the face-to-face and flipped classroom treatments, we can conclude that both approaches are effective in improving students' reading skills. Sticking to only one approach is unnecessary. Restricting the learning to one of the two approaches cannot exclusively enhance learners' reading skills. Instead, an amalgamation of faceto-face and flipped classrooms can be fruitful. At the same time, taking note of students' attitudes, intentions, social environments, behaviors, and abilities is important, as the survey results suggest. Therefore, a balanced approach based on a diagnosis of the needs of language students should be adopted for successful implementation in the language classroom. Further research can be conducted to compare Ajzen's theory of planned behavior in both face-to-face and flipped classroom approaches. In addition, the study should be replicated in various contexts to validate the results. Given the positive results for reading skills in the present study, other researchers may investigate the learners' attitudes toward flipped language learning classrooms for other language learning skills.

\section{REFERENCES}

Ajzen, I. (2015). The theory of planned behavior is alive and well, and not ready to retire: A commentary on Sniehotta, Presseau, and AraújoSoares. Health Psychology Review, 9(2), 131-137. doi: 10.1080/17437199.2014.883474

Ajzen, I. (2006). Constructing a theory of planned behavior questionnaire: Conceptual and methodological considerations. Retrieved from the University of Massachusetts Website https:/people.umass.edu/aizen/pdf/tpb.measurement.pdf 
Ajzen, I. (2007). Theory of planned behavior. In R. Baumeister \& K. Vohs (Eds.), Encyclopedia of social psychology (pp. 988-990). Thousand Oaks, CA: Sage. doi:10.4135/9781412956253.n584

Alhamami, M. (2018a). Directions to digital language learning and teaching. Createspace, Amazon.com. Retrieved from http://a.co/d/8fSKRyL

Alhamami, M. (2018b). Beliefs about and intention to learn a foreign language in face-to-face and online settings. Computer Assisted Language Learning, 31(1-2), 90-113. doi:10.1080/09588221.2017.1387154

Alhamami, M., \& Costello, H. (2019). Pre-service EFL teachers' expectations, needs, and challenges in a language learning and technology course. Journal of Language Teaching and Research, 10(3). In printing.

Andrews, T., Leonard, M., Colgrove, C., \& Kalinowski, S. (2011). Active learning not associated with student learning in a random sample of college biology courses. Life Sciences Education, 10(4), 394-405. doi:10.1187/cbe.11-07-0061

Basal, A. (2015). The implementation of a flipped classroom in foreign language teaching. Turkish Online Journal of Distance Education, 16(4), 28-37. doi:10.17718/tojde.72185

Berrett, D. (2012). How 'flipping' the classroom can improve the face to face lecture. The Chronicle of Higher Education, 12(19), 1-3.

Correa, M. (2015). Flipping the foreign language classroom and critical pedagogies: A (new) old trend. Higher Education for the Future, 2(2), 114125. doi:10.1177/2347631115584122

Fauzan, A., \& Ngabut, M. N. (2018). EFL students' perception on flipped learning in writing class. Journal on English as a Foreign Language, 8(2), 115-129. doi:10.23971/jefl.v8i2.792

Fishbein, M., \& Ajzen, I. (2011). Predicting and changing behavior: The reasoned action approach. New York, NY: Psychology Press. doi:10.4324/9780203838020

Grgurović, M., Chapelle, C. A., \& Shelley, M. (2013). A meta-analysis of effectiveness studies on computer technology-supported language learning. ReCALL, 25(2), 165-198. doi:10.1017/s0958344013000013 
Hung, H. T. (2015). Flipping the classroom for English language learners to foster active learning. Computer Assisted Language Learning, 28(1), 81-96. doi:10.1080/09588221.2014.967701

Hung, H. T. (2017). Design-based research: redesign of an English language course using a flipped classroom approach. TESOL Quarterly, 51(1), 180192. doi:10.1002/tesq.328

Lee, G., \& Wallace, A. (2018). Flipped learning in the English as a foreign language classroom: Outcomes and perceptions. TESOL Quarterly, 52(1), 62-84. doi:10.1002/tesq.372

Satar, H. M., \& Akcan, S. (2018). Pre-service EFL teachers' online participation, interaction, and social presence. Language Learning \& Technology, 22(1), $157-183$

Thyer, B. A. (2012). Quasi-experimental research designs. New York: Oxford University Press. doi:10.1093/acprof:oso /9780195387384.001.0001

Wu, W. C. V., Hsieh, J. S. C., \& Yang, J. C. (2017). Creating an online learning community in a flipped classroom to enhance EFL learners' oral proficiency. Journal of Educational Technology \& Society, 20(2), 142-157.

Zhao, Y. (2003). Recent developments in technology and language learning: A literature review and meta-analysis. CALICO Journal, 21(1), 7-27. doi:10.1558/cj.v21i1.7-27

\section{Authors' Brief CV}

Munassir Alhamami is an assistant professor at the Faculty of Languages and Translation, King Khalid University, Abha, Saudi Arabia. He received his MA degree from Trinity Western University, Canada. He received the Ph.D. degree from the University of Hawai' $i$ at Mānoa, USA.

Mohsin Raza Khan is a lecturer at the Faculty of Languages \& Translation, King Khalid University, Abha, Saudi Arabia. He received his MA (ELT) from Aligarh Muslim University, India. He has also done CELTA and Diploma in TEFL. He is the Master Reviewer for the Quality Matters (QM) and Online Facilitator of the QM. 


\section{Appendix 1: Questionnaire}

\section{STATEMENTS OF THE SURVEY ITEMS}

1. I want to learn English by watching lessons before the class time at home and doing activities and assignments during the class time inside the classroom halls in the English course this semester at the university.

[Strongly Yes; Quite Yes; Slightly Yes; Slightly No; Quite No; Strongly No].

2. Learning English by watching lessons before the class time at home and doing activities and assignments during the class time inside the classroom halls in the English course this semester at the university is.......

[Very Good; Quite Good; Slightly Good; Slightly Bad; Quite Bad; Very Bad].

3. Most people who are important to me think that I should learn English by watching lessons before the class time at home and doing activities and assignments during the class time inside the classroom halls in the English course this semester at the university.

[Strongly Yes; Quite Yes; Slightly Yes; Slightly No; Quite No; Strongly No].

4. I am confident that I can learn English by watching lessons before the class time at home and doing activities and assignments during the class time inside the classroom halls in the English course this semester at the university if I want to [Strongly Yes; Quite Yes; Slightly Yes; Slightly No; Quite No; Strongly No].

5. I intend to learn English by watching lessons before the class time at home and doing activities and assignments during the class time inside the classroom halls in the English course this semester at the university.

[Strongly Agree; Quite Agree; Slightly Agree. Slightly Disagree; Quite Disagree; Strongly Disagree].

6. Learning English by watching lessons before the class time at home and doing activities and assignments during the class time inside the classroom halls in the English course this semester at the university is

[Very Useful; Quite Useful. Slightly Useful; Slightly Useless. Quite Useless; Very Useless].

7. I feel the social motivation on me to learn English by watching lessons before the class time at home and doing activities and assignments during the class time inside the classroom halls in the English course this semester at the university.

[Strongly Yes; Quite Yes; Slightly Yes; Slightly No; Quite No; Strongly No].

Journal on English as a Foreign Language, 9(1), 71-86

Copyright @ 2019 by JEFL, p-ISSN 2088-1657; e-ISSN 2502-6615 
8. For me to learn English by watching lessons before the class time at home and doing activities and assignments during the class time inside the classroom halls in the English course this semester at the university is ....

[Very Easy; Quite Easy; Slightly Easy; Slightly Difficult; Quite Difficult; Very Difficult].

9. I aim to learn English by watching lessons before the class time at home and doing activities and assignments during the class time inside the classroom halls in the English course this semester at the university.

[Strongly Agree; Quite Agree; Slightly Agree; Slightly Disagree; Quite Disagree; Strongly Disagree].

10. Learning English by watching lessons before the class time at home and doing activities and assignments during the class time inside the classroom halls in the English course this semester at the university is.

[Very Enjoyable; Quite Enjoyable; Slightly Enjoyable; Slightly Unenjoyable; Quite Unenjoyable; Very Unenjoyable].

11. People who are important to me want me to learn English by watching lessons before the class time at home and doing activities and assignments during the class time inside the classroom halls in the English course this semester at the university.

[Strongly Yes; Quite Yes; Slightly Yes; Slightly No; Quite No; Strongly No].

12. The decision to learn English by watching lessons before the class time at home and doing activities and assignments during the class time inside the classroom halls in the English course this semester at the university is under my control. [Strongly Agree; Quite Agree; Slightly Agree; Slightly Disagree; Quite Disagree; Strongly Disagree].

13. I plan to learn English by watching lessons before the class time at home and doing activities and assignments during the class time inside the classroom halls in the English course this semester at the university.

[Strongly Agree; Quite Agree; Slightly Agree; Slightly Disagree; Quite Disagree; Strongly Disagree].

14. Learning English language by watching lessons before the class time at home and doing activities and assignments during the class time inside the classroom halls in the English course this semester at the university is ........

[Very Important; Quite Important; Slightly Important; Slightly Unimportant; Quite Unimportant; Very Unimportant]. 
15. Most people whose opinions I value would support me learning English by watching lessons before the class time at home and doing activities and assignments during the class time inside the classroom halls in the English course this semester at the university.

[Strongly Yes; Quite Yes; Slightly Yes; Slightly No; Quite No; Strongly No].

16. Whether I learn English or do not by watching lessons before the class time at home and doing activities and assignments during the class time inside the classroom halls in the English course this semester at the university is up to me. [Strongly Agree; Quite Agree; Slightly Agree; Slightly Disagree; Quite Disagree; Strongly Disagree].

17. I hope to learn English by watching lessons before the class time at home and doing activities and assignments during the class time inside the classroom halls in the English course this semester at the university.

[Strongly Yes; Quite Yes; Slightly Yes; Slightly No; Quite No; Strongly No].

18. Learning English in the English course this semester at the university is

[Very Necessary; Quite Necessary; Slightly Necessary; Slightly Unnecessary; Quite Unnecessary; Very Unnecessary].

19. People around me think that I should learn English by watching lessons before the class time at home and doing activities and assignments during the class time inside the classroom halls in the English course this semester at the university.

[Strongly Yes; Quite Yes; Slightly Yes; Slightly No; Quite No; Strongly No].

20. I am sure that I can learn English by watching lessons before the class time at home and doing activities and assignments during the class time inside the classroom halls in the English course this semester at the university if I want to [Strongly Yes; Quite Yes; Slightly Yes; Slightly No; Quite No; Strongly No]. 